\title{
Using the SNA and SAMs for a Better (Socio-)Economic
}

\section{Modelling*}

\author{
Susana Santos \\ Technical University of Lisbon, Lisbon, Portugal
}

\begin{abstract}
The Social Accounting Matrix (SAM) can be considered a tool to be used for measuring a society's activity. It provides a description of that activity, which can be either empirical or theoretical, depending on whether it is presented in a numerical or an algebraic version, respectively. Special attention will be paid here to the numerical version, and a method will be proposed for its construction from the United Nations System of National Accounts (SNA). After the first and most fundamental contribution made by Richard Stone, the SNA (with its successive improved versions, from 1953 to 2008) has established a set of rules for measuring a society's activity, which the statistical offices of countries or groups of countries have adopted and adapted to their specific realities, thus defining their own systems. Through an application of the SAM to Portugal, a basic structure, based on the SNA, will be proposed for this matrix, and its consistency within the whole system will be studied. Possible disaggregations, extensions, aggregates, indicators and balances will be calculated and other aspects beyond that basic structure will also be examined. It will be concluded that using the SNA in a SAM-based approach contributes towards a better modelling of (socio-)economic policy, emphasizing the importance of that approach as a valuable support in policy decision processes.
\end{abstract}

Keywords: social accounting matrix, national accounts, economic modelling, socio-economic modelling

\section{Introduction}

The Social Accounting Matrix (SAM) will be presented as a tool for measuring the society's activity. This approach, the SAM-based approach, can be analysed from different perspectives.

The SAM is a square matrix, in which the sum of the rows is equal to the corresponding sum of the columns. In keeping with what is conventionally accepted, the entries made in the rows represent resources, incomes, receipts or changes in liabilities and net worth, whilst the entries made in columns represent uses, outlays, expenditures or changes in assets. Thus, each transaction, which is representative of the measurable part of a society's activity, is recorded only once, in a cell of its own. Besides a rest of the world account, these figures

\footnotetext{
* The financial support provided by FCT (Fundaçãopara a Ciência e a Tecnologia), Portugal, is gratefully acknowledged. This article is part of the Strategic Project for 2011-12 (PEst-OE/EGE/UI0436/2011). And this article is based on the paper presented to the 19th International Input-Output Conference, held in Alexandria, Virginia, USA, on 13-17/6/2011.

Susana Santos, Ph.D. with Agregação (Portuguese post-doctoral degree) in Economics, Department of Economics and UECE, School of Economics and Management, Technical University of Lisbon.

Correspondence concerning this article should be addressed to Susana Santos, Rua Miguel Lupi, 20, 1249-078 Lisboa, Portugal. E-mail: ssantos@iseg.utl.pt.
} 
include both production and trade accounts and institutional accounts, which can be further subdivided into yet other accounts, defined in accordance with the purposes of the study that is being made and the available information.

With the SAM, the description of a society's activity can be either empirical or theoretical, depending on whether it is presented in a numerical or an algebraic version, respectively.

The national accounts, based on the United Nations System of National Accounts (SNA), will be considered the base source of information in the SAM-based approach, which adopts a conceptual framework based on the works of Graham Pyatt and his associates.

Section 2 presents both the numerical and algebraic versions and the corresponding perspectives of analysis in a SAM-based approach. Section 3 provides some methodological details regarding the construction of numerical versions of SAMs, together with aggregates, indicators and balances that can be calculated and the different possibilities of analysis provided by such versions. Certain aspects that lie outside the basic structure will also be examined.

The concluding remarks, presented in section 4 , systematise the main ideas of the previous sections in order to show how a SAM-based approach, using the SNA, can be a valuable contribution for a better (socio-)economic modelling.

\section{SAM: Its Numerical and Algebraic Versions}

Richard Stone and Graham Pyatt played a key role in the implementation of the SAM-based approach. Both worked on the conceptual details of that approach: the former worked more in numerical terms, within the framework of a system of national accounts, while the latter worked more in algebraic terms, mainly within the scope of input-output analysis. Their work has been decisive for understanding the importance of the SAM as a measurement tool.

In the foreword to the book that can be said to have been a pioneering work in terms of the SAM-based approach, "Social Accounting for Development Planning with special reference to Sri Lanka”, Richard Stone stated that the framework of the system of national accounts can be rearranged and:

the entries in a set of accounts can be presented in a matrix in which, by convention (...), incomings are shown in the rows and outgoings are shown in the columns; and in which, reflecting the fact that accounts balance, each row sum is equal to the corresponding column sum

That matrix, with an equal number of rows and columns, is the SAM, in the construction of which "it may be possible to adopt a hierarchical approach, first adjusting the entries in a summary set of national accounts and then adjusting subsets of estimates to these controlling totals” (Pyatt \& Roe, 1977, pp. xix, xxiii).

In turn, in the abstract to his article, "A SAM approach to modeling”, Graham Pyatt says:

Given that there is an accounting system corresponding to every economic model, it is useful to make the accounts explicit in the form of a SAM. Such a matrix can be used as the framework for a consistent dataset and for the representation of theory in what is called its transaction form.

In that transaction form (or TV (transaction value) form), the SAM can be seen... "as a framework for theory" and its cells... "can be filled instead with algebraic expressions, which describe in conceptual terms how the 
corresponding transaction values might be determined". Thus, the SAM is used as "the basic framework for model presentation” (Pyatt, 1988, pp. 327, 337).

Looking at the question from the perspectives outlined above, it can be said that a SAM can have two versions: a numerical version, which describes the activity of a society empirically; and an algebraic version, which describes that same activity theoretically. In the former version, each cell has a specific numerical value, with the sums of the rows being equal to the sums of the columns. In the latter version, each cell is filled with algebraic expressions that, together with those of all the other cells, form a SAM-based model, the calibration of which involves a replication of the numerical version.

In the words of Graham Pyatt, "the essence of (...) the SAM approach to modelling is to use the same SAM framework for both the empirical and the theoretical description of an economy” (Pyatt, 1988, p. 337).

At the same time, from the words of Richard Stone quoted above, it can be concluded that the national accounts and their underlying system play a decisive role in determining the SAM design, since they guarantee the quality of the available data and consequently give credibility to the SAM-based approach.

In 1953, with the first and most fundamental contribution written by that same author, the United Nations implemented the System of National Accounts (SNA), which had successive versions until 2008 (ISWGA, 2008). This system establishes the rules for measuring the activity of countries or groups of countries, which, in turn, have been adopted and adapted to specific realities by the corresponding statistical offices.

The construction of numerical versions of SAMs from that system will be examined below (for the construction of a specific algebraic version (Santos, 2010, 2009)).

The design of any version of a SAM will depend on the purposes for which it is to be used. However, by adopting the SNA as the underlying base source of information, a basic structure can be defined and the consistency of the whole system can be ensured.

\section{Constructing Numerical Versions of SAMs From the SNA}

The latest versions of the SNA have devoted a number of paragraphs to discussing the question of SAMs. The 2008 version mentions SAMs in Section D of Chapter 28, entitled "Input-output and other matrix-based analysis" (ISWGA, 2008, pp. 519-522), in which a matrix representation is presented of the accounts identified and described in the whole SNA. This representation is not to be identified with the SAM presented in this paper, although they both cover all the transactions recorded by those accounts. The SAM that will be presented below results from the work that the author of this paper has undertaken within a conceptual framework based on the works of Graham Pyatt and his associates (Pyatt, 1988, 1991; Pyatt \& Roe, 1977; Pyatt \& Round, 1985) and with an effort that she has made to reconcile that framework with what has been defined by (the successive versions of) the SNA.

Working within the framework of the European System of National and Regional Accounts in the European Community of 1995 (the adaptation for Europe of the 1993 version of the SNA), Santos (2007b) makes an application to Portugal at an aggregate level, explaining the main differences between these two matrices. Because the general differences between the accounts identified and described in the 1993 and 2008 versions of the SNA are not significant, this analysis still remains valid. 
The starting point for any study seeking to adopt a SAM-based approach should be the design of the SAM, i.e., the classification of its accounts. This should include identification of the problem to be studied, the purpose of that same study and knowledge of the available information.

As mentioned above, the national accounts will be considered as the base source of information. Thus, accepting that the SNA is the system underlying the national accounts, the following sections will set out the guidelines for gaining knowledge of the available information, showing its flexibility and its possibilities for characterising any problem and achieving the purposes of any study.

\section{Basic Structure and Consistency With the Whole System}

Adopting the working method recommended by Richard Stone in the second paragraph of section 2 of this paper, the basic structure for the SAM presented here will be a summary set of the national accounts and the controlling totals for the other levels of disaggregation.

In keeping with what has been the norm so far, the design of the SAM will, on the one hand, follow the conceptual framework of the works of Graham Pyatt and his associates and, on the other hand, will adhere to the conventions and nomenclature defined by the SNA. Appendix B presents an application of the following explanation to Portugal in 2007, whose national accounts adopt the European System of National and Regional Accounts in the European Community (ESA) of 1995, based on the 1993 version of the SNA. For the level of detail that is possible within the scope of this paper, the differences between the versions of 1993 (and the corresponding ESA) and 2008 of the SNA are not relevant.

Table 1 shows the above-mentioned basic structure, representing nominal transactions (" $t$ ") with which two indexes are associated. The location of these transactions in the matrix framework is described by those indexes, the first of which represents the row account and the second the column account. Each cell of this matrix will be converted into a submatrix, with the number of rows and columns corresponding to the level of disaggregation of the row and column accounts.

Table 1

The Basic SAM

\begin{tabular}{|c|c|c|c|c|c|c|c|c|}
\hline & $\mathrm{p}$ & $a$ & $\mathrm{f}$ & dic & dik & dif & rw & Total \\
\hline $\mathrm{p}$-products & $t_{p, p}$ & $\mathrm{t}_{\mathrm{p}, a}$ & 0 & $t_{\mathrm{p}, \mathrm{dic}}$ & $\mathrm{t}_{\mathrm{p}, \mathrm{dik}}$ & 0 & $t_{p, r w}$ & $t_{\mathrm{p}}$. \\
\hline$a$-activities & $\mathrm{t}_{a, \mathrm{p}}$ & 0 & 0 & 0 & 0 & 0 & 0 & $\mathrm{t}_{a}$. \\
\hline $\mathrm{f}$-factors & 0 & $\mathrm{t}_{\mathrm{f}, a}$ & 0 & 0 & 0 & 0 & $t_{f, r w}$ & $\mathrm{t}_{\mathrm{f}}$ \\
\hline dic-(domestic) institutions' current account & $t_{\text {dic,p }}$ & $\mathrm{t}_{\mathrm{dic}, a}$ & $t_{\text {dic,f }}$ & $t_{\text {dic,dic }}$ & 0 & 0 & $t_{\text {dic,rw }}$ & $t_{\text {dic }}$. \\
\hline dik—(domestic) institutions’ capital account & 0 & 0 & 0 & $t_{\text {dikdic }}$ & $t_{\text {dik,dik }}$ & $t_{\text {dik,dif }}$ & $t_{\text {dik,rw }}$ & $t_{\text {dik. }}$. \\
\hline dif-(domestic) institutions' financial account & 0 & 0 & 0 & 0 & 0 & $t_{\text {dif,dif }}$ & $t_{\text {dif,rw }}$ & $t_{\text {dif. }}$ \\
\hline rw-rest of the world & $t_{\mathrm{rw}, \mathrm{p}}$ & $\mathrm{t}_{\mathrm{rw}, a}$ & $t_{\mathrm{rw}, \mathrm{f}}$ & $t_{\mathrm{rw} \text {,dic }}$ & $\mathrm{t}_{\mathrm{rw}, \mathrm{dik}}$ & $\mathrm{t}_{\mathrm{rw}, \mathrm{dif}}$ & & $\mathrm{t}_{\mathrm{Tw}}$ \\
\hline Total & $\mathrm{t}_{\mathrm{p}}$ & $\mathrm{t}_{a} a$ & $\mathrm{t}_{\mathrm{ff}}$ & $\mathrm{t}_{\text {dic }}$ & $\mathrm{t}_{\text {dik }}$ & $\mathrm{t}_{\text {dif }}$ & $\mathrm{t}_{\mathrm{IW}_{\mathrm{w}}}$ & \\
\hline
\end{tabular}

Notes. The first three accounts ( $\mathrm{p}=$ products, $a=$ activities and $\mathrm{f}=$ factors (of production)) are the production and trade accounts of the economy and the next three accounts (dic = current; dik= capital; dif= financial) are the accounts of the (domestic) institutions. The last account (rw= rest of the world) represents the "outside” part of the (domestic) economy. Source: Santos (2010).

Table 2 shows the transactions of the National Accounts recorded in the cells of the basic SAM, which will continue to be the same if some disaggregation, or even extension, is performed - thereby preserving the consistency of the whole system. 
Table 2

The National Accounts Transactions in the Cells of the Basic SAM

\begin{tabular}{|c|c|c|c|c|}
\hline \multicolumn{3}{|c|}{ SAM } & \multicolumn{2}{|c|}{ National accounts transactions } \\
\hline row & column & Description (valuation ${ }^{a}$ ) & $\begin{array}{l}\text { (SNA) } \\
\text { code }\end{array}$ & Description (valuation (see Note a)) \\
\hline $\mathrm{p}$ & $\mathrm{p}$ & trade and transport margins & - & trade and transport margins \\
\hline $\mathrm{a}$ & $\mathrm{p}$ & production (basic prices) & $\mathrm{P} 1$ & output (basic prices) \\
\hline dic & $\mathrm{p}$ & \begin{tabular}{|lcccc} 
net taxes on products (paid to domestic \\
institutions-general government)
\end{tabular} & \multirow{2}{*}{$\begin{array}{l}\text { D21- } \\
\text {-D31 }\end{array}$} & \multirow{2}{*}{$\begin{array}{l}\text { taxes on products } \\
\text { minus } \\
\text { subsidies on products }\end{array}$} \\
\hline \multirow{2}{*}{ rw } & \multirow{2}{*}{$\mathrm{p}$} & net taxes on products (paid to the RW) & & \\
\hline & & imports (cif prices) & P7 & imports of goods and services (cif prices) \\
\hline $\mathrm{p}$ & rw & exports (fob prices) & P6 & exports of goods and services (fob prices) \\
\hline $\mathrm{p}$ & $\mathrm{a}$ & intermediate consumption (purchasers’ prices) & $\mathrm{P} 2$ & intermediate consumption (purchasers’ prices) \\
\hline $\mathrm{p}$ & dic & final consumption (purchasers’ prices) & P3 & final consumption expenditure (purchasers’ prices) \\
\hline $\mathrm{p}$ & dik & gross capital formation (purchasers' prices) & P5 & gross capital formation (purchasers’ prices) \\
\hline $\mathrm{f}$ & a & gross added value (factor cost) & $\begin{array}{l}\text { D1 } \\
\text { D4 } \\
\text { B2g } \\
\text { B3g }\end{array}$ & $\begin{array}{l}\text { compensation of employees } \\
\text { net property income } \\
\text { gross operating surplus } \\
\text { gross mixed income }\end{array}$ \\
\hline dic & a & $\begin{array}{l}\text { net taxes on production (paid to domestic } \\
\text { institutions-general government) }\end{array}$ & \multirow{2}{*}{$\begin{array}{l}\text { D29- } \\
-\mathrm{D} 39\end{array}$} & \multirow{2}{*}{$\begin{array}{l}\text { other taxes on production } \\
\text { minus } \\
\text { other subsidies on production }\end{array}$} \\
\hline rw & a & net taxes on production (paid to the RW) & & \\
\hline dic & f & gross national income & B5g & gross national income \\
\hline rw & $\mathrm{f}$ & compensation of factors to the RW & \multirow[b]{2}{*}{$\begin{array}{l}\mathrm{D} 1 \\
\mathrm{D} 4\end{array}$} & \multirow{2}{*}{$\begin{array}{l}\text { primary income paid to/received from the rest of the } \\
\text { world } \\
\text { compensation of employees } \\
\text { net property income }\end{array}$} \\
\hline $\mathrm{f}$ & rw & compensation of factors from the RW & & \\
\hline dic & dic & current transfers within domestic institutions & \multirow{3}{*}{$\begin{array}{l}\text { D5 } \\
\text { D6 } \\
\text { D7 } \\
\text { D8 }\end{array}$} & \multirow{3}{*}{$\begin{array}{l}\text { current taxes on income, wealth, etc. } \\
\text { social contributions and benefits } \\
\text { other current transfers } \\
\text { adjustment for the change in the net equity of } \\
\text { households in pension funds reserves }\end{array}$} \\
\hline rw & dic & current transfers to the RW & & \\
\hline dic & rw & current transfers from the RW & & \\
\hline dik & dic & gross saving & B8g & gross saving \\
\hline dik & dik & capital transfers within domestic nstitutions & \multirow{3}{*}{ D9 } & \multirow{3}{*}{ capital transfers } \\
\hline dik & rW & capital transfers from the RW & & \\
\hline rw & dik & capital transfers to the RW & & \\
\hline dik & dif & -net borrowing (see Note ${ }^{\mathrm{b}}$ ) & B9 & net borrowing \\
\hline dif & dif & financial transactions within domestic institutions & \multirow{3}{*}{$\begin{array}{l}\text { F1 } \\
\text { F2 } \\
\text { F3 } \\
\text { F4 } \\
\text { F5 } \\
\text { F6 } \\
\text { F7 }\end{array}$} & \multirow{3}{*}{$\begin{array}{l}\text { monetary gold and special drawing rights (SDRs) } \\
\text { currency and deposits } \\
\text { securities other than shares } \\
\text { loans } \\
\text { shares and other equity } \\
\text { insurance technical reserves } \\
\text { other accounts receivable/payable } \\
\end{array}$} \\
\hline rw & dif & financial transactions to the RW & & \\
\hline dif & rw & financial transactions from the RW & & \\
\hline $\mathrm{p}$ & total & aggregate demand & \multicolumn{2}{|c|}{ row sum of the p account's cells (see above) } \\
\hline total & $\mathrm{p}$ & aggregate supply & \multicolumn{2}{|c|}{ column sum of the p account's cells (see above) } \\
\hline $\mathrm{a}$ & total & production value & $\mathrm{P} 1$ & output (basic prices) \\
\hline total & $\mathrm{a}$ & total costs & \multicolumn{2}{|c|}{ column sum of the a account's cells (see above) } \\
\hline $\mathrm{f}$ & total & aroreato factorc income & \multicolumn{2}{|c|}{ row sum of the f account's cells (see above) } \\
\hline total & $\mathrm{f}$ & aggregate ractors income & \multicolumn{2}{|c|}{ column sum of the f account's cells (see above) } \\
\hline dic & total & & \multicolumn{2}{|c|}{ row sum of the dic account's cells (see above) } \\
\hline total & dic & aggregate income & \multicolumn{2}{|c|}{ column sum of the dic account's cells (see above) } \\
\hline
\end{tabular}


Table 2 (continued)

\begin{tabular}{|c|c|c|c|}
\hline \multicolumn{3}{|c|}{ SAM } & \multirow{2}{*}{\begin{tabular}{|l} 
Nationalaccountstransactions \\
row sum of the dik account's cells (see above)
\end{tabular}} \\
\hline dik & total & investment funds & \\
\hline total & dik & aggregate investment & column sum of the dik account's cells (see above) \\
\hline dif & total & \multirow{2}{*}{ total financial transactions } & row sum of the dif account's cells (see above) \\
\hline total & dif & & column sum of the dif account's cells (see above) \\
\hline rw & total & transactions value to the rest of the world & row sum of the rw account's cells (see above) \\
\hline total & rw & transactions value from the rest of the world & column sum of the rw account's cells (see above) \\
\hline
\end{tabular}

Notes. ${ }^{a}$ In the transactions represented by the cells whose rows and/or columns represent production accounts, as well as in the aggregates and balances that can be calculated from these, as will be seen in section 3.3, the following types of valuation are identified (regardless of whether one is working with current or constant (price) values): factor cost; basic, cifand fob prices; purchasers' or market prices. Appendix A specifies these levels; ${ }^{b}$ In the National Accounts, the net lending (+) or borrowing (-) of the total economy is the sum of the net lending or borrowing of the institutional sectors. This represents the net resources that the total economy makes available to the rest of the world (if it is positive) or receives from the rest of the world (if it is negative). The net lending (+) or borrowing (-) of the total economy is equal (but with an opposite mathematical sign) to the net borrowing (-) or lending $(+)$ of the rest of the world. In the SAM's capital account, this is considered as a component of investment funds, required/not required to cover aggregate investment. In other words, it is the financing requirement/capacity of the economy that will be covered/absorbed by financial transactions (from/to the rest of the world, since the national funds are not enough/in excess). Therefore, if there is net borrowing, we have a financing requirement that is covered by financial transactions, i.e., a resource of the capital account (row) and a use of the financial account (column). If there is net lending, we have a financing capacity that will be absorbed by financial transactions, i.e., a resource of the financial account (row) and a use of the capital account (column).Source: Santos (2010).

Schematically, the flows between the described accounts represent the circular flows in the economy that, using the SAM description, can be seen in Figure 1.

The SAM blocks, identified in Table 3, are submatrices or sets of submatrices with common characteristics. The specification of these blocks will be made below and involves an identification of the transactions of the National Accounts.

Description:

(1) Production $-\mathrm{P}$ (cell: $\mathrm{t}_{\mathrm{a}, \mathrm{p}}$ ) represents the output of goods and services (transaction P1 of the National Accounts);

(2) Domestic Tradeis represented by the value of domestically transacted products, which can be either domestically produced or imported;

- Intermediate Consumption-IC (cell: $t_{\mathrm{p}, \mathrm{a}}$ ) consists of the value of the goods and services consumed as inputs through a process of production, excluding those fixed assets whose consumption is recorded as consumption of fixed capital (transaction P2 of the National Accounts);

- Final Consumption—FC (cell: $t_{\mathrm{p}, \mathrm{dic}}$ ) consists of the expenditure incurred by resident institutional units on those goods or services that are used for the direct satisfaction of individual needs or wants, or the collective needs of members of the community (transaction P3 of the National Accounts);

- Gross Capital Formation-GCF (cell: $\mathrm{t}_{\mathrm{p}, \mathrm{dik}}$ ) includes: gross fixed capital formation (transaction P51 of the National Accounts), changes in inventories (transaction P52), and acquisitions minus disposals of valuables (transaction P53). 
DOMESTIC ECONOMY

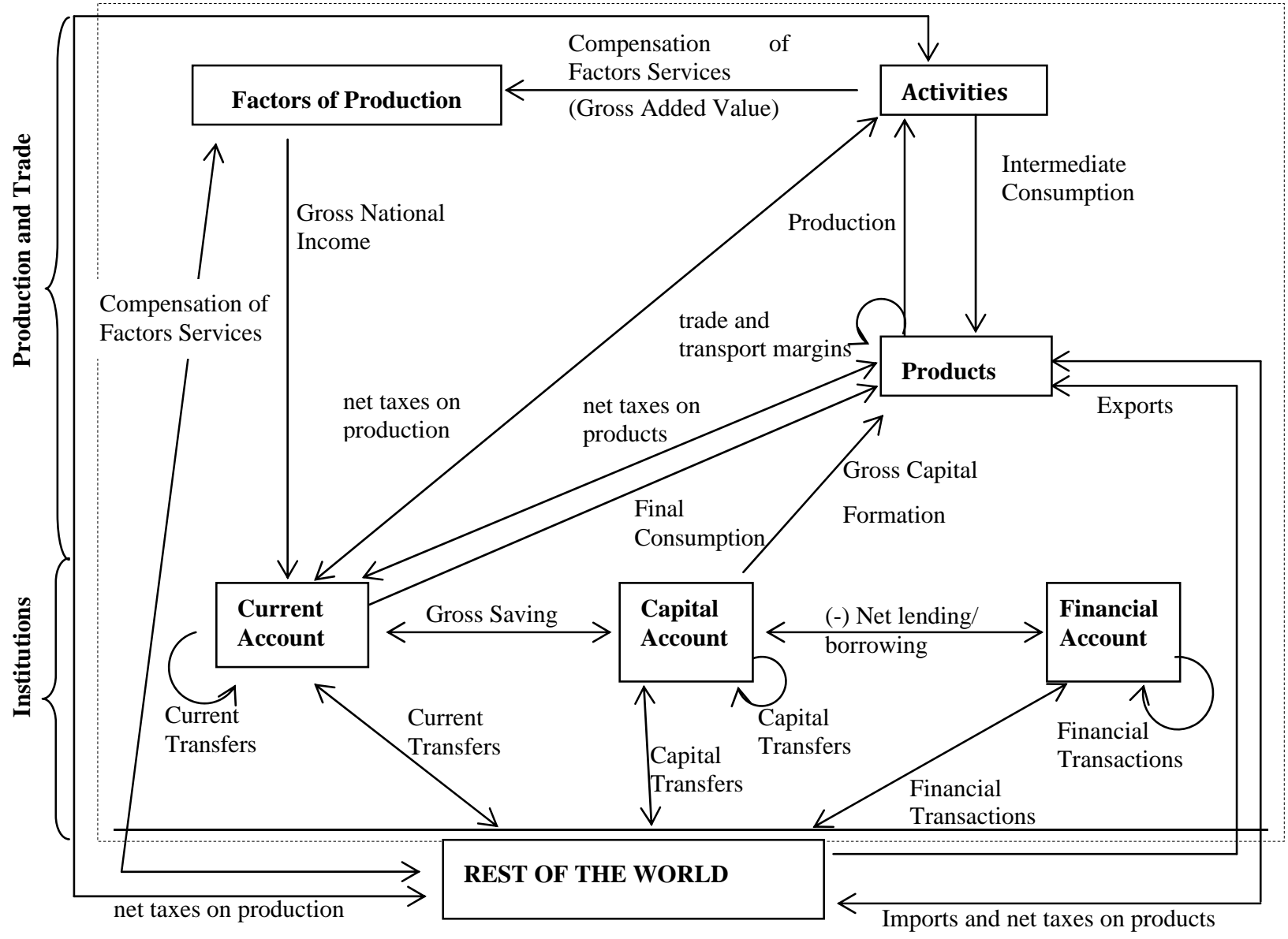

Figure 1. The nominal flows between the accounts of the basic SAM. Source: Santos (2009, p. 6).

Table 3

The Basic SAM by Blocks

\begin{tabular}{|c|c|c|c|c|c|c|c|}
\hline & $\mathrm{p}$ & $a$ & $\mathrm{f}$ & dic & dik & dif & rw \\
\hline $\mathrm{p}$-products & $\begin{array}{l}\text { TTM } \\
\left(t_{p, p}\right)\end{array}$ & $\begin{array}{l}\text { IC } \\
\left(t_{\mathrm{p}, a}\right)\end{array}$ & 0 & $\begin{array}{l}\mathrm{FC} \\
\left(\mathrm{t}_{\mathrm{p}, \mathrm{dic}}\right)\end{array}$ & $\begin{array}{l}\text { GCF } \\
\left(t_{p, d i k}\right)\end{array}$ & 0 & $\begin{array}{l}\mathrm{EX} \\
\left(\mathrm{t}_{\mathrm{p}, \mathrm{rw}}\right)\end{array}$ \\
\hline$a$-activities & $\begin{array}{l}\mathrm{P} \\
\left(\mathrm{t}_{a, \mathrm{p}}\right)\end{array}$ & 0 & 0 & 0 & 0 & 0 & 0 \\
\hline $\mathrm{f}$-factors & 0 & $\begin{array}{l}\text { CFP_GAV } \\
\left(\mathrm{t}_{\mathrm{f}, a}\right)\end{array}$ & 0 & 0 & 0 & 0 & $\begin{array}{l}\text { CFP } \\
\left(t_{f, r w}\right)\end{array}$ \\
\hline dic-(domestic) institutions' current account & $\begin{array}{l}\text { NTP } \\
\left(\mathrm{t}_{\text {dic,p }}\right)\end{array}$ & $\begin{array}{l}\text { NTA } \\
\left(\mathrm{t}_{\mathrm{dic}, a}\right)\end{array}$ & $\begin{array}{l}\text { CFP_GNI } \\
\left(t_{\text {dic,f }}\right)\end{array}$ & $\begin{array}{l}\mathrm{CT} \\
\left(\mathrm{t}_{\text {dic,dic }}\right)\end{array}$ & 0 & 0 & $\begin{array}{l}\mathrm{CT} \\
\left(\mathrm{t}_{\mathrm{dic}, \mathrm{rw}}\right)\end{array}$ \\
\hline dik-(domestic) institutions' capital account & 0 & 0 & 0 & $\begin{array}{l}\mathrm{S} \\
\left(\mathrm{t}_{\mathrm{dik}, \mathrm{dic})}\right.\end{array}$ & $\begin{array}{l}\mathrm{KT} \\
\left(\mathrm{t}_{\mathrm{dik}, \mathrm{dik}}\right)\end{array}$ & $\begin{array}{l}\text { NLB } \\
\left(t_{\text {dik,dif }}\right)\end{array}$ & $\begin{array}{l}\mathrm{KT} \\
\left(\mathrm{t}_{\mathrm{dik}, \mathrm{rw}}\right)\end{array}$ \\
\hline dif-(domestic) institutions' financial account & 0 & 0 & 0 & 0 & 0 & $\begin{array}{l}\mathrm{FT} \\
\left(\mathrm{t}_{\mathrm{dif}, \mathrm{dif}}\right)\end{array}$ & $\begin{array}{l}\mathrm{FT} \\
\left(\mathrm{t}_{\mathrm{dif}, \mathrm{rw}}\right)\end{array}$ \\
\hline rw-rest of the world & $\begin{array}{l}\text { IM\&NTP } \\
\left(t_{r w, p}\right)\end{array}$ & NTA $\left(\mathrm{t}_{\mathrm{rw}, a}\right)$ & $\mathrm{CFP}\left(\mathrm{t}_{\mathrm{rw}, \mathrm{f}}\right)$ & $\begin{array}{l}\mathrm{CT} \\
\left(\mathrm{t}_{\mathrm{rw}, \mathrm{dic}}\right)\end{array}$ & $\begin{array}{l}\mathrm{KT} \\
\left(\mathrm{t}_{\mathrm{rw}, \mathrm{dik}}\right)\end{array}$ & $\begin{array}{l}\mathrm{FT} \\
\left(\mathrm{t}_{\mathrm{rw}, \mathrm{dif}}\right)\end{array}$ & dint \\
\hline
\end{tabular}

Note.Source: Santos $(2009,2010)$.

(3) External Trade-includes the transactions in goods and services from non-residents to residents, also known as imports (transaction P7 of the National Accounts), or IM (cell: $\mathrm{t}_{\mathrm{rw}, \mathrm{p}}$ ), and the transactions in goods and 
services from residents to non-residents, also known as exports (transaction P6 of the National Accounts), or EX (cell: $\mathrm{t}_{\mathrm{p}, \mathrm{rw}}$ );

(4) Trade and Transport Margins-TTM (cell: $t_{p, p}$ ) are realised on goods purchased for resale and are a part of the production of wholesale trade services, retail trade services and the repair services of motor vehicles, motorcycles and personal and household goods. They amount to zero, since they are negative in relation to the three above-mentioned activities (because the corresponding value has already been recorded in the production submatrix), but are positive and have the same amount in relation to all the other ones;

(5) Net indirect taxes or net taxes on production and imports:

- Net Taxes on Production-NTA (cells: $t_{d i c, a} ; t_{r w, a}$ ) represents the (other) taxes on production (transaction D29 of the National Accounts) minus the (other) subsidies to production (transaction D39 of the National Accounts);

- Net Taxes on Products-NTP (cells: $t_{\text {dic,p; }}$; $t_{\mathrm{rw}, \mathrm{p}}$ ) represents the taxes on products (transaction D21 of the National Accounts) minus the subsidies on products (transaction D31 of the National Accounts).

(6) Compensation of factors of production-CFP (cells: $t_{f, a} ; t_{d i c, f} ; t_{f, r w} ; t_{r w, f}$ ) consists of the income of the institutional sectors originating from the compensation of the services provided through their real and financial assets to the activities of production and to the rest of the world, namely compensation of employees (transaction D1 of the National Accounts) and compensation of own-account assets, including the compensation of employers and/or own-account workers, and of capital, namely property income (transaction D4, balances B2g and B3g of the National Accounts);

(7) Current Transfers-CT (cells: $t_{\text {dic,dic }} ; t_{\text {dic,rw }} ; t_{r w, d i c}$ ) includes: current taxes on income, wealth, etc. (transaction D5 of the National Accounts); social contributions (transaction D61); social benefits in cash (transaction D62); other current transfers (transaction D7); and the adjustment made for the change in the net equity of households in pension fund reserves (transaction D8);

(8) Capital Transfers—KT (cells: $t_{\text {dik,dik; }}$; $t_{\text {dik,rw }}$; $t_{r w, d i k}$ ) includes: capital taxes (transaction D91 of the National Accounts), investment grants (transaction D92); other capital transfers (transaction D99); and acquisitions less disposals of non-financial non-produced assets (transaction K2);

(9) Financial Transactions-FT (cells: $\mathrm{t}_{\mathrm{dif}, \mathrm{dif}} ; \mathrm{t}_{\mathrm{dif}, \mathrm{rw}} ; \mathrm{t}_{\mathrm{rw}, \mathrm{dif}}$ ) represents the transactions in financial assets and liabilities between institutional units, and between these and the rest of the world. They are classified as monetary gold and special drawing rights; currency and deposits; securities other than shares; loans; shares and other equity; insurance technical reserves; and other accounts receivable/payable (F1-7 of the National Accounts);

(10) Gross Saving — $S$ (cell: $t_{\text {dik,dic }}$ ) measures the portion of aggregate income that is not used for final consumption expenditure and current transfers to Portuguese institutions or to the rest of the world;

(11) Net borrowing/lending—NLB (cell: $t_{\text {dik,dif }}$ ).

The net lending $(+)$ or borrowing (-) of the total economy is the sum of the net lending or borrowing of the institutional sectors. It represents the net resources that the total economy makes available to the rest of the world (if it is positive) or receives from the rest of the world (if it is negative). The net lending $(+)$ or borrowing (-) of the total economy is equal (but with an opposite mathematical sign) to the net borrowing (-) or lending $(+)$ of the rest of the world. 
Here, those amounts that fall short of (+) or exceed (-) the investment funds used to cover aggregate investment are recorded in the capital and financial accounts, since they are financial transactions either from the rest of the world (in the case of net borrowing) or to the rest of the world (in the case of net lending). This is why the mathematical signs defined in the first paragraph of this item have been exchanged.

The construction of a SAM is easier when this is performed by blocks.

The integrated economic accounts table is equivalent to a summary of everything that is measured by the SNA. According to paragraph 2.75 of the 2008 SNA:

The integrated economic accounts use (...) three of the conceptual elements of the SNA (...) (institutional units and sectors, transactions and assets and liabilities) together with the concept of the rest of the world to form a wide range of accounts. These include the full sequence of accounts for institutional sectors, separately or collectively, the rest of the world and the total economy. (ISWGNA, 2008, p. 23)

Table B1 in Appendix B is an illustration of this situation for Portugal. Based on that table, and in view of the previous description, it can be said that all the transactions recorded by the national accounts are considered in the cells of the SAM.

Therefore, as mentioned above, and again using the words of Richard Stone, the basic SAM that has just been described is the most aggregate "summary set of national accounts" and can represent a first level of the intended hierarchical method (approach), with all the controlling totals for the next level of that hierarchy.

\section{Disaggregations and Extensions}

Some other levels of the above-mentioned hierarchical method can be identified within the national accounts, providing other controlling totals for greater levels of disaggregation-with or without national accounts.

Thus, with the expected appearance of quarterly national accounts, although these will not be as complete as the annual ones, it will be possible to make some disaggregation in terms of time.

Furthermore, disaggregations can be made in terms of space, since regional accounts are also considered (Santos, 2011). Here, with the same SNA, it is possible to work with regions and countries, either individually or as a group. It would even be possible to think in world terms, if the SAM could be adopted worldwide.

Some descriptions in the following subsections are taken from Santos (2007a), so that the analysis is based on the version of 1993 of the SNA. However, as it has already been mentioned, because the level of detail is not particularly profound, there are no significant differences.

Extensions are also possible, either from the national accounts or from other sources of information.

The 2008 SNA dedicates its Chapter 28 to "Satellite accounts and other extensions" (ISWGNA, 2008, pp. 523-544), where the main idea is to serve specific analytical purposes, in a way that is consistent with the central framework, although not fully integrated into it (ISWGNA, 2008, pp. 37-38). In this respect, the author would like to support Steven Keunning and Willem Ruijter's idea of a "complete data set” which "could be tentatively labelled: a system of socio-economic accounts” (Keunning \& Ruijter, 1988, p. 73).

\section{Production and Trade Accounts}

In the basic structure described above, the production and trade accounts are the accounts of products, activities and factors of production. These accounts correspond respectively to the SNA accounts of goods and 
services, production and the primary distribution of income. Thus, within these accounts and depending on the available level of disaggregation, it can be seen how the available products are used, with some details being provided about the process of production and about how the incomes resulting from that process and the ownership of assets are distributed among institutions and activities (Santos, 2007a).

The SNA uses the Central Product Classification (CPC) Version 2 (completed in December 2008) to classify products (ISWGNA, 2008: 19), which are organised into 10 sections, with it being possible to go to the 5th level of disaggregation within each of these.

In turn, the International Standard Industrial Classification of All Economic Activities (ISIC) Revision 4 (officially released in August 2008) is used to classify the activities (ISWGNA, 2008, p. 20), organised into 23 sections, the disaggregation of which is perfectly consonant with that of the product classification. The Supply and Use Table provides this information, usually at an intermediate level of disaggregation.

As described above, in the characterisation of the block representing the compensation of factors of production, the possible disaggregation from the tables published by the national accounts is between labour (or the compensation of employees) and what the author called the compensation of own-account assets, which includes the compensation of employers and/or own-account workers, and the compensation of capital, namely property income. Such information can only be derived from the Integrated Economic Accounts Table if the products and activities accounts are not disaggregated, or from the Supply and Use Table if those accounts are disaggregated. Appendix B, which contains the above-mentioned application to Portugal, in which the products and activities accounts are not disaggregated, presents the possible disaggregation of the factors of production accounts (see Table B3) based on the Integrated Economic Accounts (see Table B1).

The extensions for tourism and health are presented by the SNA as examples of satellite accounts (ISWGNA, 2008, pp. 531-534; 538-542).

\section{Institutions and Rest of the World Accounts}

In the basic structure described above, the accounts of the domestic institutions are divided into current, capital and financial accounts. These accounts correspond respectively to the following SNA accounts: secondary distribution of income, redistribution of income in kind and use of income; capital; and financial accounts. Within these accounts, depending on the available level of disaggregation, the current accounts show how the national income is transformed into disposable income through the receipt and payment of current transfers, and how the latter is distributed between final consumption and saving. In turn, the capital account records the transactions linked to acquisitions of non-financial assets and capital transfers involving the redistribution of wealth, whereas the financial account records the transactions in financial assets and liabilities between institutional units, and between these and the rest of the world (Santos, 2007a).

All the linkages between the domestic economy and the rest of the world, i.e., all the transactions between resident and non-resident units, are recorded both in the SAM and in the SNA through the rest of the world account (Santos, 2007a).

Chapter 4 of the 2008 SNA specifies the institutional sectors, including the rest of the world, and their possible disaggregation, which in some cases can be taken as far as the third level (ISWGNA, 2008, pp. 61-85), although normally it cannot be taken beyond the first level. In the case of the rest of the world, such 
disaggregation will certainly depend on the country, or group of countries, that adopt and adapt this system.

At the first level of disaggregation, the accounts of the institutions, as well as the rest of the world account, are part of the Integrated Economic Accounts Table. Higher levels of disaggregation, whenever these are possible, are usually published in separate accounts.

Even at the first level of disaggregation, any work conducted with the institutional sectors requires, in addition to the Integrated Economic Accounts or the Accounts of the Institutions, the so-called "from whom to whom matrices”, which are not normally published, but can be acquired from the national statistical offices. These matrices make it possible to fill in the cells of the submatrices of transactions taking place within domestic institutions, recorded in the above-described blocks of current and capital transfers and financial transactions.

As far as this aspect is concerned, the author would like to underline the importance of the information provided by the possible disaggregations of the financial account, especially in a SAM framework, in which interactions can be identified at many different levels.

The disaggregation of specific institutional sectors makes it possible to analyse the most diverse aspects of a society's activity: income distribution, with disaggregated households and factor of production accounts (Santos, 2009, is an example of this); the role of the government and its subsectors, with a disaggregated general government (Santos, 2004, 2007b, are also examples); the role of the non-profit institutions serving households, as well as of the non-financial and/or financial corporations, etc..

Appendix B, which contains the above-mentioned application to Portugal, presents a possible disaggregation of the institutions' current and capital accounts (see Table B3), made from the Integrated Economic Accounts (see Table B1) and the "from whom to whom matrices", described in the sources of the corresponding Table (B3). Due to the unavailability of "from whom to whom matrices" for financial transactions, the financial account could not be disaggregated.

\section{Aggregates, Indicators and Balances}

As was seen above, all the transactions of the national accounts are covered by the SAM, so that macro-economic aggregates, indicators and balances can be identified from it (see the description of the cells or blocks in Tables 1 or 3).

Gross Domestic Product at market prices $\left(\mathrm{GDP}_{\mathrm{pm}}\right)$, which is usually considered the main macro-economic aggregate, can be calculated in the three known approaches:

- Production approach: $\mathrm{GDP}_{\mathrm{pm}}=\mathrm{P}-\mathrm{IC}+\mathrm{NTP}=\mathrm{t}_{\mathrm{a}, \mathrm{p}}-\mathrm{t}_{\mathrm{p}, \mathrm{a}}+\left(\mathrm{t}_{\mathrm{dic}, \mathrm{p}}+\right.$ (part of $\left.) \mathrm{t}_{\mathrm{rw}, \mathrm{p}}\right)$;

- Expenditure approach: GDPpm $=\mathrm{FC}+\mathrm{GCF}+\mathrm{Ex}-\mathrm{IM}=\mathrm{t}_{\mathrm{p}, \mathrm{dic}}+\mathrm{t}_{\mathrm{p}, \mathrm{dik}}+\mathrm{t}_{\mathrm{p}, \mathrm{rw}}-$ (part of) $\mathrm{t}_{\mathrm{rw}, \mathrm{p}}$;

- Income approach: GDPpm $=$ GAV + NTP $+N T A=t_{f, a}+\left(t_{d i c, p}+(\right.$ part of $\left.) t_{r w, p}\right)+\left(t_{d i c, a}+t_{r w, a}\right)$.

Domestic Product can be converted into National Product by adding the compensation of factors received from the rest of the world and deducting the compensation of factors and the net indirect taxes (on both products and production) sent to the rest of the world. Thus, from the described cells of the basic SAM, GDP $\mathrm{pm}_{\text {can }}$ be converted into Gross National Product at market prices $\left(\mathrm{GNP}_{\mathrm{pm}}\right)$ or Gross National Income $\left(\mathrm{GNI}_{\mathrm{pm}}\right)$, as follows: $\mathrm{GDP}_{\mathrm{pm}}+\mathrm{t}_{\mathrm{f}, \mathrm{rw}}-\mathrm{t}_{\mathrm{rw}, \mathrm{f}}-\mathrm{t}_{\mathrm{rw}, \mathrm{a}}-$ (part of) $\mathrm{t}_{\mathrm{rw}, \mathrm{p}}$. On the other hand, as the SAM directly provides Gross National Income at factor cost, this can also be calculated just by adding the net indirect taxes (on both products and production) received by domestic institutions: $t_{d i c, f}+t_{d i c, p}+t_{d i c, a}$. 
In turn, gross aggregates can be converted into net aggregates (and balances) by deducting the consumption of the fixed capital (transaction K1 of the National Accounts, which lies outside the basic SAM, as it will be seen in Section 3.4, but is part of the Integrated Economic Accounts)

Disposable Income (Domestic or National; Gross or Net) is also very important and can be calculated by adding to $\mathrm{GNI}_{\mathrm{pm}}$ the net current transfers received by domestic institutions: $\mathrm{GNI}_{\mathrm{pm}}+\left((\right.$ received $\left.) \mathrm{t}_{\mathrm{dic}, \mathrm{dic}}+\mathrm{t}_{\mathrm{dic}, \mathrm{rw}}\right)-$ ((paid) $t_{\text {dic,dic }}+t_{r w, d i c}$.

Gross Saving (S) and Net Lending or Borrowing (NLB) are given directly by the SAM, through $\mathrm{t}_{\text {dik,dic }}$ and $t_{\text {dik,dif }}$, respectively.

It is also possible to calculate structural indicators of the functional and institutional distribution of generated income, as well as indicators of the use of disposable income.

In the functional distribution of generated income, the distribution of gross added value (at factor cost, GAV) among factors of production is given by the structure of the sub-matrix in the cell $\left(\mathrm{t}_{\mathrm{f}, \mathrm{a}}\right)$ of the basic structure, with its level of detail depending on the disaggregation of the activities (column account) and of the factors of production (row account).

In the institutional distribution of generated income, the distribution of gross national income (at factor cost, GNI) is given by the structure of the sub-matrix in the cell ( $\left.t_{\text {dic,f }}\right)$ of the basic structure. In this case, the level of detail will depend on the disaggregation of the factors of production (column account) and of the current account of the domestic institutions (row account).

As it was seen above, by excluding from gross national income the current transfers paid to other institutions and to the rest of the world, and by including the current transfers received from the other institutions and from the rest of the world (and, in the case of the government, the net indirect taxes), the institutional distribution of gross disposable income can also be studied. In turn, the use made of gross disposable income is divided into final consumption and saving, although non-financial and financial corporation do not have any final consumption.

Some additional data can allow for the study of additional details, for instance per capita indicators with demographic information.

The main items in the balance sheets of the institutional sectors and of the rest of the world can be calculated from the respective rows and columns. The former will be referred to as budgets and the latter as the balance of payments. Their total balance is their net lending/borrowing (NLB); the current budget balance is the respective gross saving (S); and the capital balance is the difference between the first and the second.

The results of an application to Portugal can be seen in Appendix B.

\section{Going Beyond the Basic Structure}

In order to improve the snapshot given by the SAM, as described above, some rearrangements could be made to the described cell contents and/or some zero cells could be filled in. This can be done either within and/or outside the scope of the SNA:

(1) Within the scope of the SNA, the following topics are examples of rearrangements that could be made to the described cells' contents (the described cells can be identified in Tables 1 or 3 ) in order to avoid the existence of negative cells in the SAM. This would help to improve its definition (incomings in rows and outgoings in columns) and facilitate the application of certain balancing methods, whenever necessary. 
(a) Instead of working with net indirect taxes, it is possible to work with taxes and subsidies separately. The taxes on products and on production could be recorded in the above-described NTP ( $\left.t_{\text {dic,p }} ; t_{\mathrm{rw}, \mathrm{p}}\right)$ and NTA ( $\mathrm{t}_{\mathrm{dic}, \mathrm{a}}$; $t_{r w, a}$ ) blocks, respectively. The subsidies on products could be recorded in cells $t_{p, d i c}$ and $t_{p, r w}$. The subsidies on production would then be recorded in cells $\mathrm{t}_{\mathrm{a}, \mathrm{dic}}$ and $\mathrm{t}_{\mathrm{a}, \mathrm{r}}$;

(b) The net lending or borrowing (NLB) could be recorded in cells $t_{\text {dik,dif, }}$ in the case of net borrowing, and in cells $\mathrm{t}_{\mathrm{dif}, \mathrm{dik}}$, in the case of net lending.

(2) Still working within the scope of the SNA, some new data could be considered, either in addition to other data or as possible replacements for these figures.

(a) The consumption of fixed capital could be included in $\mathrm{t}_{\mathrm{p}, \mathrm{dik}}$;

(b) The production of the institutional sectors could be included in $t_{\text {dic,p }}$. In the basic structure, production is recorded in cells $\mathrm{t}_{\mathrm{a}, \mathrm{p}}$;

(c) The intermediate consumption of the institutional sectors could be included in $t_{\mathrm{p}, \mathrm{dic}}$. In the basic structure, intermediate consumption is recorded in cells $t_{\mathrm{p}, \mathrm{a}}$.

(3) Outside the scope of the SNA, working either within or outside the framework of the satellite accounts, the inclusion of the following aspects could be considered.

(a) The expansion of the production boundary, for example recording the services that households deliver to themselves. The extension to unpaid household activity is presented by the SNA as an example of satellite accounts (ISWGNA, 2008, pp. 542-543);

(b) The consideration of informal aspects of the economy, to which SNA dedicates the Chapter 25 (ISWGNA, 2008, pp. 471-482);

(c) The (re)analysis of the imputations; the underlying methodologies and possible adjustment;

(d) Demography and the activity of the population of working age, their time use, skills, etc.;

(e) The rethinking of the way in which the factors of production are worked upon and the possible consideration of natural resources and their relationship with the society's activity. The extension to environmental accounting is presented by the SNA as an example of satellite accounts (ISWGNA, 2008, pp. 534-538);

(f) Stocks of capital and wealth.

The author knows that the implementation and study of some of these topics, especially those referred to in subsection (3) above, could become valuable research projects, and that, in fact, some of them are already part of the SNA's research agenda. However, the aim here is to show that, although the SAM-based approach (especially when based on the SNA) is a very complete and credible measurement tool, there is still much that can be done to improve it.

It should be noted that the SAM-based approach involves both a numerical and an algebraic version of the SAM. As it was mentioned above, in the former version, each cell assumes a specific numerical value, with the sums of the rows being equal to the sums of the columns, whereas, in the latter, each cell is represented by algebraic expressions that, together with those of all the other cells, represent a SAM-based model, the calibration of which involves a replication of the numerical version. Without undermining that principle, SAM-based models can be developed and extended. Such extensions can be supported by additional data, encompassing aspects such 
as those referred to in (3) (d)-(f). Santos (2009) is an example of such research, where the use of some of the aspects referred to in (3) (d) was tested and proved to be possible.

\section{Concluding Remarks}

Together, the United Nations System of National Accounts (SNA) is flexible enough and the Social Accounting Matrix (SAM)-based approach versatile enough to contribute towards a better (socio-) economic modelling. Under such conditions, the sectors of production can be worked upon in conjunction with the institutional sectors, using the national accounts as the base source of information.

A SAM-based approach incorporates two versions of the SAM. A numerical version of the SAM describes the activity of a society empirically. In this version, each cell has a specific numerical value, with the sums of the rows being equal to the sums of the columns. In turn, an algebraic version describes that same activity theoretically. Each cell of the latter version contains algebraic expressions that, together with those of all the other cells, make up a SAM-based model, the calibration of which involves a replication of the numerical version. Without altering this principle in any way, SAM-based models can be developed with extensions and can be supported by additional data.

Using the SNA in a SAM-based approach will facilitate:

- Multi-period and dynamic analysis, since national accounts are published regularly;

- Identification of the network of nominal links existing within the (socio-)economic system, allowing for the particularisation of regions, products (goods and services), activities (industries), institutions or sets of institutions (households, enterprises, government), etc.;

- Study of the processes of production, trade and the distribution, redistribution and accumulation of income;

- Evaluation of the impacts of alternative policy measures and the consequent policy decision, i.e., the processes of decision-making and decision-taking;

- Better use of the quantitative information available, since the SNA has developed national accounts that are increasingly consistent and in harmony with all other statistics.

However, both within and outside the scope of the SNA, there are several important aspects that still need to be completed. Some rearrangements can be made to the described cell contents and/or some zero cells can be filled in. Coverage of those aspects could establish the essential difference between the SAM-based approach described in this paper and any other approach to (socio-) economic modelling.

Therefore, unless they have certain specific studies that they wish to undertake, rather than use their resources to construct National Accounting Matrices or Social Accounting Matrices, the Statistical Offices and other producers of national accounts should seek to provide the most complete and accurate information possible (bearing in mind what was said in section 3) to those who have to undertake specific tasks of their own. This will enable them to use and manipulate the data according to their needs.

By using a SAM-based approach, with a consistent and credible numerical version and a corresponding well-defined algebraic version of a SAM, it will be possible to achieve better (socio-) economic modelling. A SAM that is suitably designed to address a specific problem or set of problems can result in a fully interlinked macro-model, which can play an invaluable role, for example, in providing quantitative support in the policy 
decision processes.

\section{References}

Inter-Secretariat Working Group on National Accounts (ISWGNA). (2008). System of National Accounts (2008 SNA) United Nations Statistics Division and the United Nations regional commissions, New York; International Monetary Fund (IMF), Washington, D.C.; World Bank, Washington, D.C.; Organisation for Economic Cooperation and Development (OECD), Paris; Statistical Office of the European Communities, Eurostat, Brussels/Luxembourg.

Keuning S., \& Ruijter, W. (1988). Guidelines to the construction of a social accounting matrix. Review of Income and Wealth, 34, $71-100$.

Pyatt, G. (1988). A SAM approach to modeling. Journal of Policy Modeling, 10, 327-352.

Pyatt, G. (1991). Fundamentals of social accounting. Economic Systems Research, 3, 315-341.

Pyatt, G., \& Roe, A. (1977). Social accounting for development planning with special reference to Sri Lanka. Cambridge, UK: Cambridge University Press.

Pyatt, G., \& Round, J. (1985). Accounting and fixed price multipliers in a social accounting matrix framework. In G. Pyatt, \& J. Round (Eds.), Social accounting matrices. A basis for planning (pp. 52-69). Economic Journal, 89(356), 850-873.

Santos, S. (2004). Portuguese net borrowing and the government budget balance. A SAM approach. Journal of Policy Modeling, 26, 703-717.

Santos, S. (2007a). Macro-SAMs for modelling purposes. An application to Portugal in 2003. Working paper No. 17/2007/ Department of Economics/Research Unit on Complexity and Economics, ISEG-UTL.

Santos, S. (2007b). Modelling economic circuit flows in a social accounting matrix framework. An application to Portugal. Applied Economics, 39, 1753-1771.

Santos, S. (2009). From the System of National Accounts (SNA) to a Social Accounting Matrix (SAM)-Based Model. An Application to Portugal. Coimbra-Portugal, Edições Almedina.

Santos, S. (2010). A quantitative approach to the effects of social policy measures. An application to Portugal, using Social Accounting Matrices. MPRA (Munich Personal RePEc Archive) Paper No. 23676; EERI (Economics and Econometrics Research Institute) RP (Research Papers) 2010/33.

Santos, S. (2011). The underlying database of an instrument for economic and social policy analysis for the Azores. Application and extension to 2005. Working paper No. 14/2011/CEEAplA (Research Centre for Applied Economics in the Atlantic), University of Azores and Madeira.

\section{Appendix A: Levels of Valuation}

The following types of valuation are identified in the transactions represented by those cells whose rows and/or columns are production accounts, as well as in the aggregates and balances that can be calculated from these, regardless of whether one is working with current or constant (price) values: factor cost; basic, cif and fob prices; purchasers' or market prices.

Factor cost represents the compensation of the factors (or the primary incomes due to labour and capital) used in the production process of the domestic economy, excluding taxes on production and imports (taxes on products and other taxes on production) and subsidies (subsidies on products and other subsidies on production). This type of valuation is considered in the SNA (Paragraph 265) to be complementary (ISWGNA, 2008, p. 22).

When other taxes on production, net of other subsidies on production, are added to the production value of the domestic economy at factor cost, we obtain the basic prices for the production that will be transacted in the domestic market and the fob (free on board) price level of the part that will be exported. Imports, valued at cif (cost-insurance-freight included) prices, will be added at this level to the unexported part of domestic production that will be transacted in the domestic market.

Purchasers' or market prices relate to those products, either domestically produced or imported, that are transacted in the domestic market. Here, the basic/cif prices will be increased by adding to them the trade and transport margins and the taxes net of subsidies on products. 


\section{Appendix B: Application to Portugal}

Table B1

Portuguese Integrated Economic Accounts for 2007 (in Millions of Euros)

\begin{tabular}{|c|c|c|c|c|c|c|c|c|c|c|c|}
\hline \multirow{2}{*}{ Accounts } & \multirow[b]{2}{*}{ Total } & \multirow{2}{*}{$\begin{array}{l}\text { Goods and } \\
\text { services } \\
\text { account } \\
\text { (resources) }\end{array}$} & \multirow{2}{*}{\begin{tabular}{|l|} 
S.2 \\
Rest of \\
the world \\
account
\end{tabular}} & \multirow{2}{*}{\begin{tabular}{|l|} 
S.1 \\
Total of \\
the \\
economy \\
\end{tabular}} & \multirow{2}{*}{\begin{tabular}{|l} 
S.15 \\
NPISHs
\end{tabular}} & \multirow{2}{*}{\begin{tabular}{|l} 
S.14 \\
House-holds
\end{tabular}} & \multirow{2}{*}{\begin{tabular}{|l|} 
S.13 \\
$\begin{array}{l}\text { General } \\
\text { government }\end{array}$
\end{tabular}} & \multirow{2}{*}{\begin{tabular}{|l|} 
S.12 \\
$\begin{array}{l}\text { Financial } \\
\text { corporations }\end{array}$
\end{tabular}} & \multirow{2}{*}{\begin{tabular}{|l|} 
S.11 \\
$\begin{array}{l}\text { Non-financial } \\
\text { corporations }\end{array}$ \\
\end{tabular}} & \multirow[b]{2}{*}{ Code } & \multirow[b]{2}{*}{$\begin{array}{l}\text { Transactions and other } \\
\text { flows, stocks and } \\
\text { balancing items }\end{array}$} \\
\hline & & & & & & & & & & & \\
\hline \multirow{9}{*}{$\begin{array}{lr}\text { I. } & \text { Production/ } \\
\text { external } & \text { account } \\
\text { of goods } & \text { and } \\
\text { services } & \end{array}$} & 68,045 & 68,045 & & & & & 5,300 & & & P.7 & $\begin{array}{l}\text { Imports of goods and } \\
\text { services }\end{array}$ \\
\hline & 54,514 & & 54,514 & & & & & & & P.6 & $\begin{array}{l}\text { Exports of goods and } \\
\text { services }\end{array}$ \\
\hline & 317,058 & 317,058 & & & & & & & & P. 1 & $\begin{array}{l}\text { Output of goods and } \\
\text { services }\end{array}$ \\
\hline & 171,360 & & & 171,360 & 2,238 & 12667 & 7,048 & 5,207 & 144,201 & P. 2 & $\begin{array}{l}\text { Intermediate } \\
\text { consumption }\end{array}$ \\
\hline & 23,039 & 23,039 & & 23,039 & & & & & & $\begin{array}{l}\text { D.21- } \\
\text { D.31 }\end{array}$ & Net taxes on products \\
\hline & 168,737 & & & 168,737 & 2,677 & 29,383 & 23,131 & 10,978 & 79,528 & \begin{tabular}{|l|} 
B.1g \\
$/$ B.1g
\end{tabular} & $\begin{array}{l}\text { Gross added value/gross } \\
\text { domestic product }\end{array}$ \\
\hline & 28,351 & & & 28,351 & 551 & 8,576 & 3,257 & 673 & 15,293 & K.1 & $\begin{array}{l}\text { Consumption of fixed } \\
\text { capital }\end{array}$ \\
\hline & 140,386 & & & 140,386 & 2,125 & 20,808 & 19,874 & 10,305 & 64,235 & $\begin{array}{l}\text { B.1n } \\
\text { /B.1n }\end{array}$ & $\begin{array}{l}\text { Value added, net/Net } \\
\text { domestic product }\end{array}$ \\
\hline & 13,531 & & 13,531 & & & & & & & B. 11 & $\begin{array}{l}\text { External balance of } \\
\text { goods and services }\end{array}$ \\
\hline \multirow{7}{*}{$\begin{array}{l}\text { II. 1.1. } \\
\text { Generation } \\
\text { of income }\end{array}$} & 83,123 & & 247 & 82,876 & 2,313 & 5,600 & 20,271 & 4,137 & 50,556 & D.1 & $\begin{array}{l}\text { Compensation } \\
\text { employees }\end{array}$ \\
\hline & 24,982 & & & 24,982 & 4 & 635 & & 30 & 652 & D.2 & $\begin{array}{l}\text { Taxes on production and } \\
\text { imports }\end{array}$ \\
\hline & $-2,808$ & & & $-2,808$ & -184 & -750 & -341 & -3 & -909 & D3 & Subsidies \\
\hline & 46,612 & & & 46,612 & 544 & 6,822 & 3,201 & 6,815 & 29,229 & B. $2 \mathrm{~g}$ & Gross operating surplus \\
\hline & 17,076 & & & 17,076 & & 17,076 & & & & B.3g & Gross mixed income \\
\hline & 20,618 & & & 20,618 & -8 & 604 & -56 & 6,142 & 13,936 & B. $2 n$ & Net operating surplus \\
\hline & 14,719 & & & 14,719 & & 14,719 & & & & B.3n & Net mixed income \\
\hline \multirow{3}{*}{$\begin{array}{l}\text { II.1.2. } \\
\text { Allocation } \\
\text { of primary } \\
\text { income }\end{array}$} & 76,011 & & 12,809 & 63,201 & 165 & 8,101 & 4,821 & 26,645 & 23,469 & D.4 & Property income \\
\hline & 163,394 & & & 163,394 & 946 & 117,680 & 22,877 & 5,918 & 15,972 & B.5g & $\begin{array}{l}\text { Gross national income/ } \\
\text { Gross balance of } \\
\text { primary incomes }\end{array}$ \\
\hline & 135,043 & & & 135,043 & 395 & 109,104 & 19,620 & 5,245 & 679 & B.5n & $\begin{array}{l}\text { Net national income/ } \\
\text { Net balance of primary } \\
\text { incomes }\end{array}$ \\
\hline \multirow{6}{*}{$\begin{array}{l}\text { II.2. Secondary } \\
\text { distribution } \\
\text { income }\end{array}$} & 16,112 & & 21 & 16,092 & 6 & 9,717 & 21 & 1,399 & 4,949 & D.5 & \begin{tabular}{|lc} 
Current taxes & on \\
income, wealth, etc & \\
\end{tabular} \\
\hline & 25,264 & & 71 & 25,193 & & 25,193 & & & & D.61 & Social contributions \\
\hline & 29,742 & & 48 & 29,694 & 49 & 48 & 24,611 & 3,271 & 1,715 & D.62 & $\begin{array}{l}\text { Social benefits other } \\
\text { than social transfers in } \\
\text { kind }\end{array}$ \\
\hline & 17,222 & & 4,702 & 12,520 & 67 & 3,837 & 3,859 & 2,278 & 2,480 & D.7 & Other current transfers \\
\hline & 165,107 & & & 165,107 & 3,199 & 115,202 & 32,232 & 5,000 & 9,473 & B.6g & $\begin{array}{ll}\begin{array}{l}\text { Gross } \\
\text { income }\end{array} & \text { disposable } \\
\end{array}$ \\
\hline & 136,756 & & & 136,756 & 2,648 & 106,627 & 28,975 & 4,327 & $-5,821$ & B.6n & Net disposable income \\
\hline \multirow{3}{*}{$\begin{array}{l}\text { II.3. } \\
\text { Redistri-bution of } \\
\text { in-come in kind }\end{array}$} & 22,143 & & & 22,143 & 3,415 & & 18,728 & & & D.63 & Social transfers in kind \\
\hline & 165,107 & & & 165,107 & -216 & 137,345 & 13,504 & 5,000 & 9,473 & B.7g & $\begin{array}{l}\text { Gross } \begin{array}{l}\text { adjusted } \\
\text { disposable income }\end{array} \\
\end{array}$ \\
\hline & 136,756 & & & 136,756 & -767 & 128,769 & 10,247 & 4,327 & $-5,821$ & B.7n & $\begin{array}{l}\text { Net adjusted disposable } \\
\text { income }\end{array}$ \\
\hline \multirow{8}{*}{$\begin{array}{l}\text { II } 4 . \quad \text { Use of } \\
\text { income }\end{array}$} & 165,107 & & & 165,107 & 3,199 & 115,202 & 32,232 & 5,000 & 9,473 & B.6g & $\begin{array}{|lr|}\begin{array}{l}\text { Gross } \\
\text { income }\end{array} & \text { disposable } \\
\end{array}$ \\
\hline & 136756 & & & 136,756 & 2,648 & 106,627 & 28,975 & 4,327 & $-5,821$ & B.6n & Net disposable income \\
\hline & 143634 & & & 143,634 & 3,415 & 107,220 & 32,999 & & & P. 4 & $\begin{array}{|lc|}\begin{array}{l}\text { Actual } \\
\text { Consumption }\end{array} & \text { Final } \\
\end{array}$ \\
\hline & 143634 & & & 143,634 & & 129,363 & 14,272 & & & P.3 & $\begin{array}{l}\text { Final consumption } \\
\text { expenditure }\end{array}$ \\
\hline & 569 & & & 569 & & & & 569 & & D.8 & $\begin{array}{l}\text { Adjustment for the } \\
\text { change in the net equity } \\
\text { of households in } \\
\text { pension funds reserves }\end{array}$ \\
\hline & 21473 & & & 21,473 & -216 & 8,551 & -767 & 4,432 & 9,473 & B.8g & Gross saving \\
\hline & \begin{tabular}{|l|}
-6878 \\
\end{tabular} & & & $-6,878$ & -767 & -25 & $-4,024$ & 3,759 & $-5,821$ & B.8n & Net saving \\
\hline & 17162 & & 17162 & & & & & & & B.12 & Current external balance \\
\hline
\end{tabular}


(Table B1 continued)

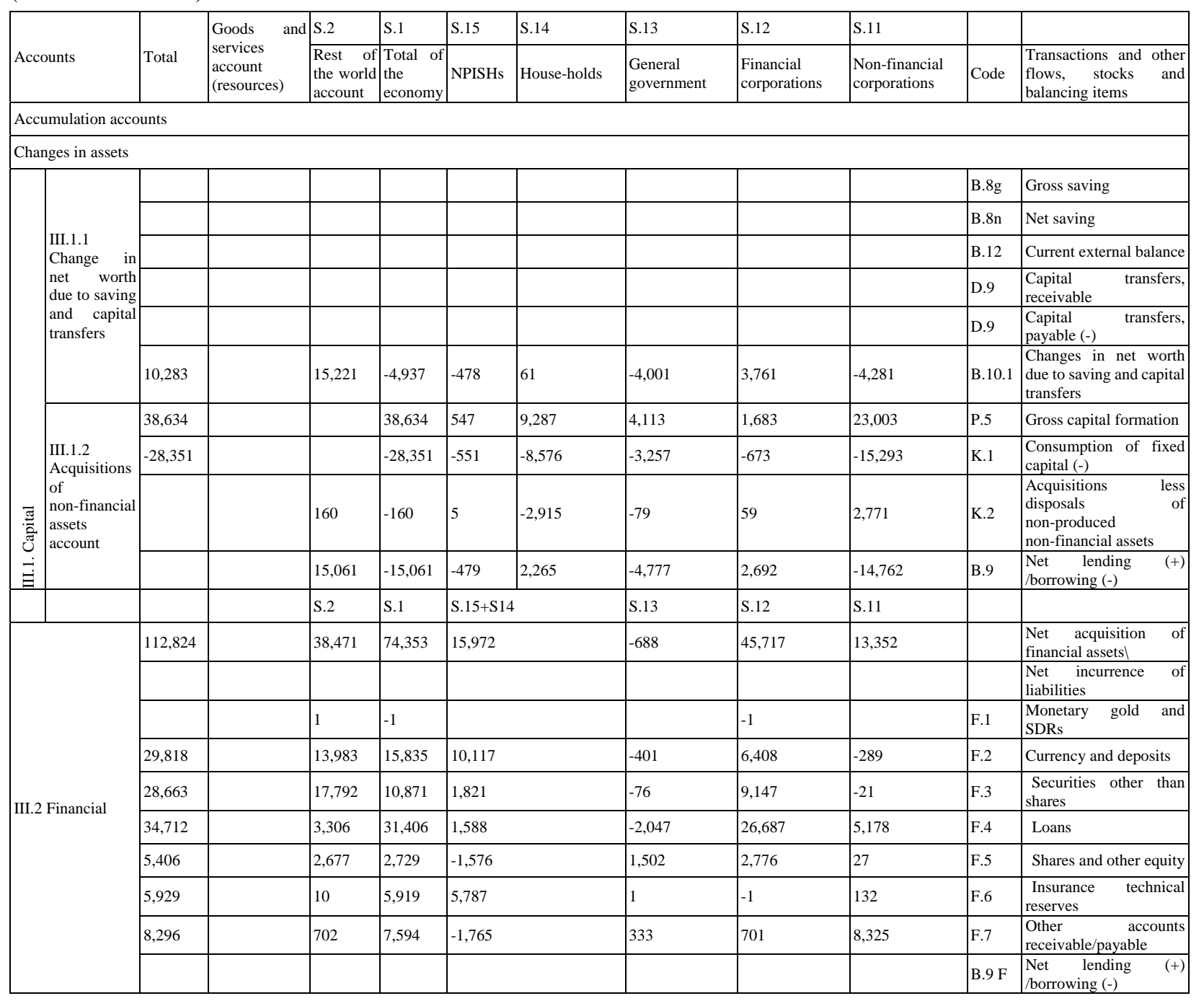

Table B1

Portuguese Integrated Economic Accounts for 2007 (in Millions of Euros) (Continued)

\begin{tabular}{|c|c|c|c|c|c|c|c|c|c|c|c|}
\hline \multirow[b]{2}{*}{$\begin{array}{l}\text { Transactions } \\
\text { and other } \\
\text { flows, stocks } \\
\text { and balancing } \\
\text { items }\end{array}$} & \multirow{2}{*}{ Code } & S.11 & S.12 & S.13 & S.14 & S.15 & S.1 & S.2 & \multirow[b]{2}{*}{$\begin{array}{l}\text { Goods and } \\
\text { Services } \\
\text { Account } \\
\text { (Resources) }\end{array}$} & \multirow[b]{2}{*}{ Total } & \multirow[b]{2}{*}{ Accounts } \\
\hline & & $\begin{array}{l}\text { Non-Financial } \\
\text { Corporations }\end{array}$ & $\begin{array}{l}\text { Financial } \\
\text { Corporations }\end{array}$ & $\begin{array}{l}\text { General } \\
\text { Government }\end{array}$ & House-holds & NPISHs & \begin{tabular}{|l|} 
Total of \\
the \\
Economy
\end{tabular} & \begin{tabular}{|l|} 
Rest of \\
the \\
World \\
Account
\end{tabular} & & & \\
\hline $\begin{array}{lr}\begin{array}{l}\text { Imports } \\
\text { goods } \\
\text { services }\end{array} & \text { and } \\
\end{array}$ & P.7 & & & & & & & 68,045 & & 68,045 & \multirow{5}{*}{$\begin{array}{l}\text { I. Production } \\
\text { external account } \\
\text { of goods and } \\
\text { services }\end{array}$} \\
\hline $\begin{array}{lr}\begin{array}{l}\text { Exports } \\
\text { goods } \\
\text { services }\end{array} & \text { of } \\
\end{array}$ & P.6 & & & & & & & & 54,514 & 54,514 & \\
\hline $\begin{array}{lr}\begin{array}{l}\text { Output } \\
\text { goods } \\
\text { services }\end{array} & \text { of } \\
\text { and } \\
\end{array}$ & P.1 & 223,729 & 1,6185 & 30,179 & 42,050 & 4,915 & 317,058 & & & 317,058 & \\
\hline $\begin{array}{l}\text { Intermediate } \\
\text { consumption }\end{array}$ & P. 2 & & & & & & & & 171,360 & 171,360 & \\
\hline $\begin{array}{l}\text { Net taxes on } \\
\text { products }\end{array}$ & D.21-D31 & & & & & & 23,039 & & & 23,039 & \\
\hline
\end{tabular}


(Table B1 continued)

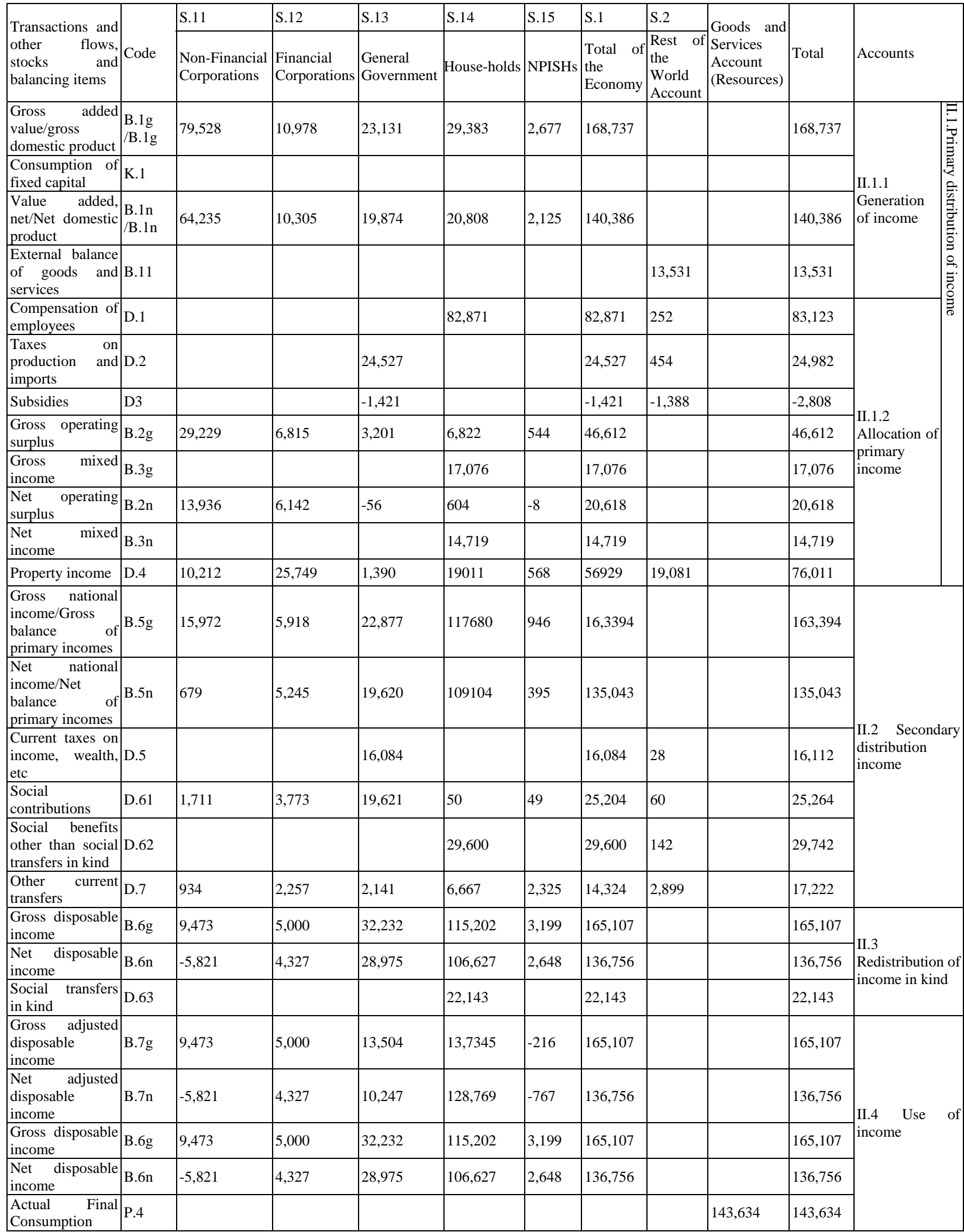


(Table B1 continued)

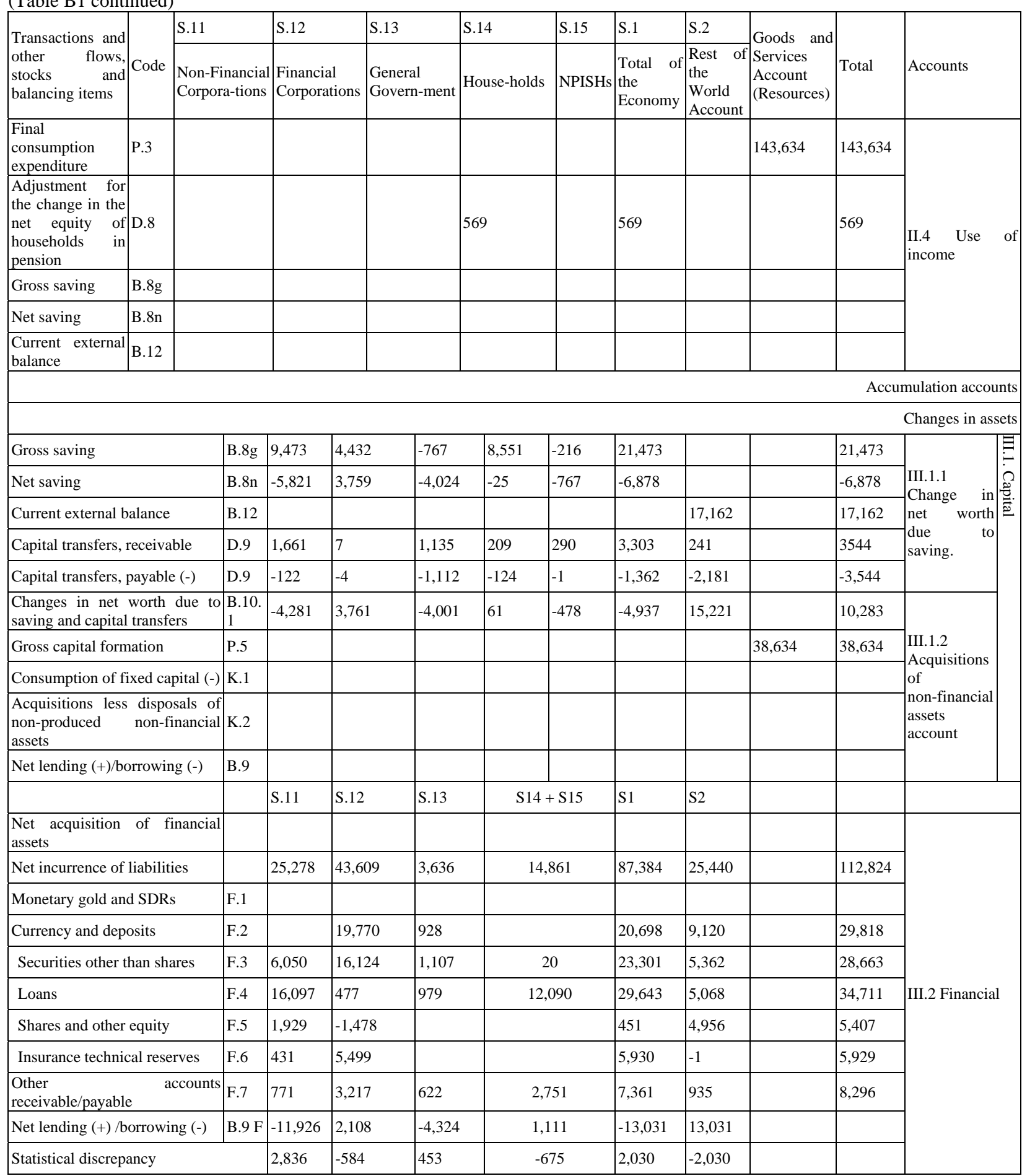

Note. Sources: Statistics Portugal (INE); Portuguese Central Bank (Banco de Portugal). 
Table B2

Portuguese Basic SAM for 2007 (in Millions of Euros)

\begin{tabular}{|c|c|c|c|c|c|c|c|c|}
\hline & $\mathrm{p}$ & $a$ & $\mathrm{f}$ & dic & dik & dif & rw & Total \\
\hline $\mathrm{p}$-products & 0 & 171,360 & & 141,615 & 38,634 & & 54,514 & 406,123 \\
\hline$a$-activities & 317,058 & & & & & & & 317,058 \\
\hline $\mathrm{f}$-factors & & 146,564 & & & & & 13,056 & 159,620 \\
\hline dic-(domestic) institutions' current account & 22,876 & 230 & 140,287 & 80,940 & & & 4,841 & 249,175 \\
\hline dik-(domestic) institutions' capital account & & & & 21,473 & 1,122 & 15,061 & 2,341 & 39,997 \\
\hline dif-(domestic) institutions' financial account & & & & & & 48,913 & 38,471 & ,87,384 \\
\hline rw-rest of the world & 66,188 & $-1,096$ & 19,333 & 5,147 & 241 & 23,410 & & 113,223 \\
\hline Total & 406,123 & 317,058 & 159,620 & 249,175 & 39,997 & 87,384 & 113,223 & \\
\hline
\end{tabular}

Note. Direct purchases abroad by residents are considered as a current transfer to the rest of the world. Source: Table B1.

Table B3 (a)

Portuguese Basic SAM for 2007, with Disaggregated Factors of Production and the (Domestic) Institutions' Current and Capital Accounts (in Millions of Euros)

\begin{tabular}{|c|c|c|c|c|c|c|c|c|c|c|c|c|c|c|}
\hline \multirow{4}{*}{\multicolumn{4}{|c|}{$\begin{array}{l}\text { Outlays (expenditures) } \\
\text { Incomes (receipts) }\end{array}$}} & \multicolumn{5}{|c|}{ Production } & \multicolumn{6}{|c|}{ Institutions } \\
\hline & & & & \multirow{3}{*}{\begin{tabular}{|l} 
Products \\
1
\end{tabular}} & \multirow{3}{*}{\begin{tabular}{|l} 
Activities \\
2
\end{tabular}} & \multicolumn{3}{|l|}{ Factors } & \multicolumn{6}{|c|}{ Current account } \\
\hline & & & & & & \multirow{2}{*}{\begin{tabular}{|l|}
$\begin{array}{l}\text { Labour } \\
\text { (employees) }\end{array}$ \\
3
\end{tabular}} & \multirow{2}{*}{\begin{tabular}{|l|}
$\begin{array}{l}\text { Own } \\
\text { assets }\end{array}$ \\
4
\end{tabular}} & \multirow{2}{*}{ Total } & \multirow{2}{*}{\begin{tabular}{|l|} 
Households \\
5
\end{tabular}} & \multirow{2}{*}{$\begin{array}{l}\text { Enterprises } \\
6\end{array}$} & \multirow{2}{*}{\begin{tabular}{|l}
$\begin{array}{l}\text { Financial } \\
\text { corporations }\end{array}$ \\
7
\end{tabular}} & \multirow{2}{*}{$\begin{array}{l}\text { Government } \\
8\end{array}$} & \multirow{2}{*}{\begin{tabular}{|l|} 
NPISH \\
9
\end{tabular}} & \multirow[t]{2}{*}{ Total } \\
\hline & & & & & & & & & & & & & & \\
\hline \multirow{5}{*}{ 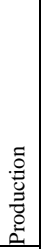 } & \multicolumn{2}{|c|}{ Products } & 1 & 0 & 171,360 & 0 & 0 & 0 & 105,201 & 0 & 0 & 32,999 & 3,415 & 141,615 \\
\hline & \multicolumn{2}{|c|}{ Activities } & 2 & 317,058 & 0 & 0 & 0 & 0 & 0 & 0 & 0 & 0 & 0 & 0 \\
\hline & \multirow{3}{*}{ 总 } & Labour (employees) & 3 & 0 & 0 & 0 & 0 & 0 & 0 & 0 & 0 & 0 & 0 & 0 \\
\hline & & Own assets & 4 & 0 & 0 & 0 & 0 & 0 & 0 & 0 & 0 & 0 & 0 & 0 \\
\hline & & \multicolumn{2}{|l|}{ Total } & 0 & 146,564 & 0 & 0 & 0 & 0 & 0 & 0 & 0 & 0 & 0 \\
\hline & \multirow{6}{*}{ 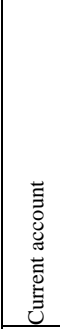 } & Households & 5 & 0 & 0 & 82,871 & 34,809 & 117,680 & 792 & 1,715 & 5,093 & 25,060 & 64 & 32,725 \\
\hline & & \begin{tabular}{|l|l|}
$\begin{array}{l}\text { Enterprises } \\
\text { (nonfinancial corporations) }\end{array}$ \\
\end{tabular} & 6 & 0 & 0 & 0 & 15,972 & 15,972 & 1,711 & 0 & 705 & 141 & 0 & 2,557 \\
\hline & & Financial corporations & 7 & 0 & 0 & 0 & 5,918 & 5,918 & 5,143 & 627 & 133 & 24 & 29 & 5,957 \\
\hline & & Government & 8 & 22,876 & 230 & 0 & -230 & -230 & 29,427 & 6,423 & 1,429 & 21 & 27 & 37,328 \\
\hline & & $\begin{array}{|ll|}\text { Non Profit } & \text { Institutions } \\
\text { Serving } & \text { Households } \\
\text { (NPISH) } & \\
\end{array}$ & 9 & 0 & 0 & 0 & 946 & 946 & 521 & 149 & 44 & 1,660 & 0 & 2,374 \\
\hline & & Total & & 22,876 & 230 & 82,871 & 57,416 & 140,287 & 37,594 & 8,914 & 7,405 & 26,905 & 121 & 80,940 \\
\hline \multirow{7}{*}{ 葛 } & \multirow{6}{*}{ 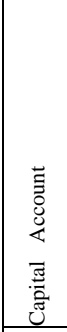 } & Households & 10 & 0 & 0 & 0 & 0 & 0 & 8,551 & 0 & 0 & 0 & 0 & 8,551 \\
\hline & & \begin{tabular}{|ll}
$\begin{array}{l}\text { Enterprises } \\
\text { corporations) }\end{array}$ \\
\end{tabular} & 11 & 0 & 0 & 0 & 0 & 0 & 0 & 9,473 & 0 & 0 & 0 & 9,473 \\
\hline & & Financial corporations & 12 & 0 & 0 & 0 & 0 & 0 & 0 & 0 & 4,432 & 0 & 0 & 4,432 \\
\hline & & Government & 13 & 0 & 0 & 0 & 0 & 0 & 0 & 0 & 0 & -767 & 0 & -767 \\
\hline & & \begin{tabular}{|ll}
$\begin{array}{l}\text { Non Profit } \\
\text { Ser-ving }\end{array}$ & Institutions \\
(NPISH) & Households \\
\end{tabular} & 14 & 0 & 0 & 0 & 0 & 0 & 0 & 0 & 0 & 0 & -216 & -216 \\
\hline & & Total & & 0 & 0 & 0 & 0 & 0 & 8,551 & 9473 & 4,432 & -767 & -216 & 21,473 \\
\hline & \multicolumn{2}{|c|}{ Financial account } & 15 & 0 & 0 & 0 & 0 & 0 & 0 & 0 & 0 & 0 & 0 & 0 \\
\hline \multicolumn{3}{|c|}{ Rest of the world } & 16 & 66,188 & $-1,096$ & 252 & 19,081 & 19,333 & 3,221 & 230 & 111 & 1,586 & 0 & 5,147 \\
\hline \multicolumn{4}{|c|}{ Total } & 406123 & 317,058 & 83,123 & 76,498 & 159,620 & 154,567 & 18,617 & 11,948 & 60,723 & 3,320 & 249,175 \\
\hline
\end{tabular}

Note. Source: Statistics Portugal (INE); Portuguese Central Bank (Banco de Portugal)(Integrated Economic Accounts-Table B1;

"from whom to whom matrices" for the transactions D39 and D5-9- see Table 2) 
Table B3 (b)

Portuguese Basic SAM for 2007, with Disaggregated Factors of Production and the (Domestic) Institutions' Current and Capital Accounts (in Millions of Euros) (Continued)

\begin{tabular}{|c|c|c|c|c|c|c|c|c|c|c|c|c|}
\hline \multicolumn{4}{|c|}{ Outlays (expenditures) } & \multicolumn{7}{|c|}{ Institutions } & \multirow{4}{*}{ Rest of the world } & \multirow{4}{*}{ Total } \\
\hline \multirow{3}{*}{\multicolumn{4}{|c|}{ Incomes (receipts) }} & \multicolumn{6}{|c|}{ Capital Account } & \multirow{2}{*}{$\begin{array}{l}\text { Financial } \\
\text { Account }\end{array}$} & & \\
\hline & & & & Households & Enterprises & \begin{tabular}{|l} 
Financial \\
corporations
\end{tabular} & Government & NPISH & \multirow{2}{*}{ Total } & & & \\
\hline & & & & 10 & 11 & 12 & 13 & 14 & & 15 & & \\
\hline \multirow{5}{*}{ 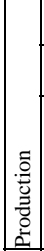 } & \multicolumn{2}{|c|}{ Products } & 1 & 9,287 & 23,003 & 1,683 & 4,113 & 547 & 38,634 & 0 & 54,514 & 406,123 \\
\hline & \multicolumn{2}{|c|}{ Activities } & 2 & 0 & 0 & 0 & 0 & 0 & 0 & 0 & 0 & 317,058 \\
\hline & \multirow{3}{*}{ 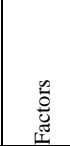 } & Labour (employees) & 3 & 0 & 0 & 0 & 0 & 0 & 0 & 0 & 247 & 83,123 \\
\hline & & Own assets & 4 & 0 & 0 & 0 & 0 & 0 & 0 & 0 & 12,809 & 76,498 \\
\hline & & Total & & 0 & 0 & 0 & 0 & 0 & 0 & 0 & 13,056 & 159,620 \\
\hline & \multirow{6}{*}{ 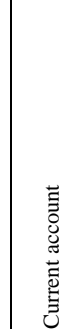 } & Households & 5 & 0 & 0 & 0 & 0 & 0 & 0 & 0 & 4,162 & 154,567 \\
\hline & & \begin{tabular}{|l} 
Enterprises (nonfinancial \\
corporations)
\end{tabular} & 6 & 0 & 0 & 0 & 0 & 0 & 0 & 0 & 88 & 18,617 \\
\hline & & Financial corporations & 7 & 0 & 0 & 0 & 0 & 0 & 0 & 0 & 73 & 11,948 \\
\hline & & Government & 8 & 0 & 0 & 0 & 0 & 0 & 0 & 0 & 518 & 60,723 \\
\hline & & $\begin{array}{|ll|}\begin{array}{l}\text { Non-profit } \\
\text { serving }\end{array} & \text { institutions } \\
\text { (NPISH) } & \text { households } \\
\end{array}$ & 9 & 0 & 0 & 0 & 0 & 0 & 0 & 0 & 0 & 3,320 \\
\hline & & Total & & 0 & 0 & 0 & 0 & 0 & 0 & 0 & 4,841 & 249,175 \\
\hline \multirow{7}{*}{ 号 } & \multirow{6}{*}{ 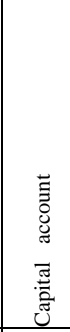 } & Households & 10 & 0 & 0 & 2 & 75 & 0 & 77 & $-2,265$ & 3,048 & 9,411 \\
\hline & & \begin{tabular}{|l} 
Enterprises (nonfinancial \\
corporations)
\end{tabular} & 11 & 0 & 0 & 0 & 749 & 0 & 749 & 14,762 & $-1,859$ & 23,125 \\
\hline & & Financial corporations & 12 & 0 & 0 & 2 & 1 & 0 & 3 & $-2,692$ & -55 & 1,688 \\
\hline & & Government & 13 & 11 & 22 & 0 & 0 & 1 & 34 & 4,777 & 1,181 & 5,225 \\
\hline & & \begin{tabular}{|ll} 
Non-profit & institutions \\
serving & households \\
(NPISH) & \\
\end{tabular} & 14 & 0 & 0 & 0 & 259 & 0 & 259 & 479 & 26 & 549 \\
\hline & & Total & & 11 & 22 & 4 & 1,084 & 1 & 1,122 & 15,061 & 2,341 & 39,997 \\
\hline & \multicolumn{2}{|c|}{ Financial account } & 15 & 0 & 0 & 0 & 0 & 0 & 0 & 48,913 & 38,471 & 87,384 \\
\hline \multicolumn{3}{|c|}{ Rest of the world } & 16 & 113 & 100 & 0 & 28 & 0 & 241 & 23,410 & & 113,223 \\
\hline \multicolumn{4}{|c|}{ Total } & 9,411 & 23,125 & 1,688 & 5,225 & 549 & 39,997 & 87,384 & 113,223 & \\
\hline
\end{tabular}

Notes. Source: Statistics Portugal (INE); Portuguese Central Bank (Banco de Portugal)(Integrated Economic Accounts-Table B1; "from whom to whom matrices" for the transactions D39 and D5-9- see Table 2).

Table B4

Portuguese Macroeconomic Aggregates in 2007 (in Millions of Euros)

\begin{tabular}{lcr}
\hline & Millions of euros \\
\hline Gross domestic product at market prices (GDP) & 168,737 \\
Gross national income (at market prices) (GNIMP) & 163,394 \\
\hline & Households & 115,771 \\
& Non-financial corporations & 9,473 \\
& Financial corporations & 4,432 \\
Gross Disposable Income (DI), of & General government & 32,232 \\
& Non-profit institutions serving households & 3,199 \\
\cline { 2 - 3 } & Total & 165,107 \\
\hline
\end{tabular}

Note. Source: Table B3. 
Table B5

Portuguese Functional Distribution of the Income Generated in 2007 (in Percentage Terms)

\begin{tabular}{ll}
\hline & $\%$ \\
\hline Factors of Production (generated income = gross added value, at factor cost) & 56.5 \\
Labour (employees) & 43.5 \\
Own assets (employers and/or own-account workers; capital) & 100.0 \\
\hline Total & \\
\hline
\end{tabular}

Source: Table B3.

Table B6

Portuguese Institutional Distribution of the Income Generated in 2007 (in Percentage Terms)

\begin{tabular}{|c|c|c|c|}
\hline & \multicolumn{3}{|c|}{ Factors of Production } \\
\hline & $\begin{array}{l}\text { Labour } \\
\text { (employees) }\end{array}$ & $\begin{array}{l}\text { Own assets } \\
\text { (employers and/or } \\
\text { own-account } \\
\text { workers; capital) } \\
\end{array}$ & Total \\
\hline \multicolumn{4}{|c|}{ Institutions (generated income = gross national income) } \\
\hline Households & 100.0 & 60.6 & 83.9 \\
\hline Non-financial corporations & & 27.8 & 11.4 \\
\hline Financial corporations & & 10.3 & 4.2 \\
\hline General government & & -0.4 & -0.2 \\
\hline Non-profit institutions serving households & & 1.6 & 0.7 \\
\hline Total & 100.0 & 100.0 & 100.0 \\
\hline
\end{tabular}

Note. Source: Table B3.

Table B7

Portuguese Distribution and Use of Disposable Income Among Institutions, in 2007 (in Percentage Terms)

\begin{tabular}{|c|c|c|c|}
\hline & \multirow{2}{*}{$\begin{array}{l}\text { Distribution of disposable } \\
\text { income }\end{array}$} & \multicolumn{2}{|c|}{ Use of disposable income } \\
\hline & & Final consumption & Saving \\
\hline Households & 70.1 & 92.6 & 7.4 \\
\hline Non-financial corporations & 5.7 & & 100.0 \\
\hline Financial corporations & 2.7 & & 100.0 \\
\hline General government & 19.5 & 102.4 & -2.4 \\
\hline Non-profit institutions serving households & 1.9 & 106.7 & -6.7 \\
\hline Total & 100.0 & 87.0 & 13.0 \\
\hline
\end{tabular}

Note. Source: Table B3.

Table B8

Portuguese Government and Households Budget in 2007 (in Millions of Euros)

\begin{tabular}{|c|c|c|c|c|c|c|c|c|}
\hline & \multicolumn{3}{|l|}{ Resources or receipts (row) } & \multicolumn{3}{|l|}{ Uses or expenditure (column) } & \multicolumn{2}{|l|}{ Balance } \\
\hline & & Government & Households & & Government & Households & Government & Households \\
\hline \multirow[t]{6}{*}{$\begin{array}{l}1 . \quad \text { Current } \\
\text { Account (a) }\end{array}$} & & 60,723 & 154,567 & & 61,490 & 146,015 & -767 & 8,551 \\
\hline & $\begin{array}{l}\text { Gross National Income at } \\
\text { factor cost }\end{array}$ & -230 & 117,680 & Final consumption & 32,999 & 105,201 & & \\
\hline & Net taxes on production & 230 & 0 & $\begin{array}{l}\text { Current transfers to domestic } \\
\text { institutions }\end{array}$ & 26,905 & 37,594 & & \\
\hline & Net taxes on products & 22,876 & 0 & Current transfers to the RW & 1,586 & 3,221 & & \\
\hline & \begin{tabular}{|l|l|} 
Current transfers from \\
domestic institutions
\end{tabular} & 37,328 & 32,725 & & & & & \\
\hline & $\begin{array}{l}\text { Current transfers from the } \\
\text { RW }\end{array}$ & 518 & 4,162 & & & & & \\
\hline \multirow[t]{4}{*}{\begin{tabular}{ll|}
$2 . \quad$ Capital \\
Account
\end{tabular}} & & 1,215 & 3,125 & & 5,225 & 9,411 & $-4,010$ & $-6,286$ \\
\hline & $\begin{array}{l}\text { Capital transfers from } \\
\text { domestic institutions }\end{array}$ & 34 & 77 & Gross capital formation & 4,113 & 9,287 & & \\
\hline & $\begin{array}{l}\text { Capital transfers from the } \\
\text { RW }\end{array}$ & 1,181 & 3,048 & $\begin{array}{l}\text { Capital transfers to domestic } \\
\text { institutions }\end{array}$ & 1,084 & 11 & & \\
\hline & & & & Capital transfers to the RW & 28 & 113 & & \\
\hline $3=1+2(b)$ & & 61,938 & 157,691 & & 66,715 & 155,426 & $-4,777$ & 2,265 \\
\hline
\end{tabular}

Notes. (a) Balance $=$ Gross saving. (b) Balance $=-$ Net lending $(+) /$ borrowing (-). Source: Table B3 (rows/columns 5, 8, 10 and 13). 
Table B9

Portuguese Balance of the Transactions With the Rest of the World or Balance of Payments in 2007 (in Millions of Euros)

\begin{tabular}{|l|l|l|l|l|l|}
\hline & \multicolumn{2}{|c|}{ Resources (row) } & \multicolumn{2}{c|}{ Uses (column) } & Balance \\
\hline 1. Current Account & & 72,411 & & 89,573 & $-17,162$ \\
\hline - Goods \& Services & Exports & 54,514 & Imports & 68,045 & $-13,531$ \\
\hline - Income & Compensation of factors from the RW & 13,056 & Compensation of factors to the RW & 19,333 & $-6,277$ \\
\hline - Current transfers & Current transfers from the RW & 4,841 & $\begin{array}{l}\text { Current transfers to the RW + net taxes on } \\
\text { production to the RW + net taxes on } \\
\text { production to the RW }\end{array}$ & 2,195 & 2,646 \\
\hline 2. Capital Account & Capital transfers from the RW & 2,341 & Capital transfers to the RW & 241 & 2,101 \\
\hline $\begin{array}{l}\text { 3 = } 1+2 \text { (Balance = Net } \\
\text { borrowing) }\end{array}$ & & 74,752 & & 89,813 & $-15,061$ \\
\hline 4. Financial Account & Financial transfers from the RW & 38,471 & Financial transfers to the RW & 23,410 & 15,061 \\
\hline 5 = 3 + 4 = Total & & 113,223 & & 113,223 & 0 \\
\hline
\end{tabular}

Note. Source: Table B3 (row/column 16). 